\title{
After Hinckley: The Insanity Defense Reexamined
}

The Insanity Defense and the Trial of John W. Hinckley, Jr. By Lincoln Caplan. Boston: David R. Godine, Publisher, Inc., 1984. Pp. 135. $\$ 13.95$.

\section{Jonathan B. Sallet†}

An expert psychiatrist testified for the defense that John W. Hinckley, Jr., could not be held accountable for shooting the President of the United States because he was "suffering from a major depressive disorder and from process schizophrenia . . . "N No, replied the government, Hinckley was sane and should be found guilty because, as its expert testified, he was only "suffering from dysthymic disorder, or depressive neurosis, and from three types of personality disorder-schizoid, narcissistic, and mixed-the last with borderline and passive-aggressive features."2

These snatches of expert testimony demonstrate, I think, that a contested insanity defense almost invariably requires that a lay jury decide the degree to which a defendant is mentally ill, and not merely whether a defendant is mentally ill. After all, most of us would agree that a person who attempts to assassinate the President at close range and in broad daylight is, to use the vernacular, "crazy." But on what grounds does a jury decide whether that defendant is so removed from normal behavior that basic jurisprudential rules of personal culpability no longer apply? And, when a jury is asked to make that determination, to what degree does psychiatric testimony actually enable it "to make a sensible and educated determination about the mental condition of the defendant at the time of the offense[?]'s

This murky intersection of psychiatry and law is the subject of Lincoln

$\dagger$ Mr. Sallet is associated with the Washington, D.C. law firm of Miller, Cassidy, Larroca \& Lewin and, in that capacity, assisted in the representation of two fact-witnesses who testified in the trial of United States v. Hinckley. Neither witness offered an expert opinion on Mr. Hinckley's mental state.

1. L. Caplan, The Insanity Defense and the Trial of John W. Hinckley, Jr. 68 (1984) [hereinafter cited by page number only].

2. P. 69.

3. Ake v. Oklahoma, 53 U.S.L.W. 4179, 4183 (U.S. Feb. 26, 1985). As discussed infra at text accompanying notes $12-19$, the Supreme Court held in Ake that an indigent defendant's access to psychiatric assistance is constitutionally mandated where the defendant's sanity is likely to be a significant factor at trial. 
Caplan's book, The Insanity Defense and the Trial of John W. Hinckley, $J r$. As the title suggests, the trial of John Hinckley is the lens through which Caplan views the history of and current controversy surrounding the insanity defense. Mr. Hinckley is not the exclusive focus of the book, however; Gaplan also shows us the workings of the insanity defense in the case of Rufus Adams, an indigent tried during the same period in the Superior Court of the District of Columbia. From his observations of these two trials and of recent legislative actions to curb the use of the insanity defense, Caplan concludes that efforts to abolish or limit the defense constitute a false trade-off: Liberty is sacrificed without a concommitant gain in increased security for members of society. While Caplan's critique of recent congressional reform efforts is overly broad, his account of the Hinckley trial, and his assessment of the implications of the trial for the future of both the insanity defense and civil liberties, are worthy of wide attention.

I.

Neither Caplan's conclusions nor the surrounding debate can be adequately discussed without an understanding of the differing legal formulations of the insanity defense, or of the facts of the Hinckley case. Consider the following three hypotheticals. First, a man strangles his wife while believing that he is actually throttling a ceramic duck. Because homicide is a crime that requires a showing of specific intent, that defendant will not need to rely on the insanity defense in order to escape a guilty verdict. The defendant never formed the intent to murder a human being, and the government, therefore, will be unable to prove the mens rea element of the crime. In 1982, the Reagan Administration proposed that Congress effectively abolish the insanity defense by limiting the introduction of evidence of mental disease or defect to situations in which the defendant failed to form the intent necessary to commit the crime. Thus, as thenAttorney General Smith explained, a defendant on trial for committing murder with a handgun could raise a defense based on his mental state "only if the defendant did not even know he had a gun in his hand or thought, for example, that he was shooting at a tree."

Second, a man strangles his wife fully intending to kill her, but does so believing that she is controlled by extra-terrestrials who are using her as part of a conspiracy to conquer Earth. This defendant does have the mens rea necessary to support a verdict of homicide because he intended to murder a human being. But he committed the act at a time when, "as a result of a severe mental disease or defect, [he] was unable to appreciate

4. P. 111 . 
the nature and quality or the wrongfulness of his acts." Under this "cognitive" standard, which was endorsed by the American Psychiatric Association ("A.P.A."), and recently codified by Congress, the defendant is not guilty by reason of insanity. ${ }^{6}$ The abolitionist view, however, would treat this defendant as guilty of homicide because he had the necessary mens rea when committing the crime.

Third, a man strangles his wife intending to kill her, while knowing it is wrong to do so. He asserts that he had previously quarrelled with his wife and that he was so enraged that he was unable to prevent himself from taking murderous revenge. At trial, his attorney argues that, because of mental illness, the defendant lacked the capacity to conform his behavior to the requirements of the law. Such a contention-if believed by the jury-would establish a defense of insanity under the jury instruction given at the Hinckley trial and under the standard proposed by the American Law Institute, both of which include a "volitional" element concerned with a defendant's ability to behave in accordance with legal requirements. ${ }^{7}$ The defendant would be guilty, however, under the new federal statute and the A.P.A. proposal: Each treats as irrelevant the issue whether a defendant could conform his actions to the requirements of the law. Of course, the abolition of the insanity defense once advocated by the Reagan Administration would also result in a guilty verdict in this case.

The essential facts of the Hinckley case are by now well-known. John W. Hinckley, Jr., entered Texas Tech University in 1974. For the next seven years he drifted about, residing at various times in Texas, California, and Colorado. During the summer of 1976, Hinckley lived in Hollywood where he watched the film Taxi Driver fifteen times at a local theater. Taxi Driver is the story of Travis Bickle, who intends to assassinate a presidential candidate but who instead saves a twelve-year-old prostitute, played by Jodie Foster, by shooting her pimp and one of her customers. Because of his new-found hero status, Travis is finally able to

5. Insanity Defense Reform Act of 1984 , Pub. L. No. 98-473, § 402(a), 1984 U.S. Code ConG. \& AD. NEwS (98 Stat.) 2057 (to be codified at 18 U.S.C. $\$ 20$ ).

6. In 1982, the American Psychiatric Association announced its support of the cognitive standard, see American Psychiatric Association, Statement on the Insanity Defense 11-12 (Dec. 1982), and Congress enacted it into law in 1984. See supra note 5.

7. The jury at the Hinckley trial was instructed on both the cognitive and the volitional standards. The judge explained that:

The burden is on the Government to prove beyond a reasonable doubt either that the defendant was not suffering from a mental disease or defect on March 30,1981 , or else that he nevertheless had substantial capacity on that date both to conform his conduct to the requirements of the law and to appreciate the wrongfulness of his conduct.

P. 97. This instruction is based on the proposal of the American Law Institute that: "A person is not responsible for criminal conduct if at the time of such conduct as a result of mental disease or defect he lacks substantial capacity either to appreciate the criminality (wrongfulness) of his conduct or to conform his conduct to the requirements of the law." MODEL PENal Code $\$ 4.01$, at 66 (Proposed Official Draft 1962). 
attract the attention of a beautiful woman he earlier had pursued unsuccessfully.

By the fall of 1980, Hinckley was apparently obsessed with two people: Jodie Foster and the President of the United States. During the next few months Hinckley repeatedly flew to New Haven, telephoned Foster, and left her notes. He also purchased handguns and tracked President Carter's campaign travels, first to Dayton, Ohio, and then to Nashville, Tennessee. In March, 1981, Hinckley again traveled to New Haven and left handwritten notes for Foster.

On March 30, 1981, Hinckley was in Washington, D.C., where he read President Reagan's schedule in a local newspaper, loaded his handgun with Devastator bullets-which explode on impact-and left a letter in his hotel room addressed to Foster. The letter read, in part:

There is a definite possibility that I will be killed in my attempt to get Reagan. . . .

... [T] he reason I'm going ahead with this attempt now is because I just cannot wait any longer to impress you. . . . By sacrificing my freedom and possibly my life, I hope to change your mind about me. ${ }^{8}$

That afternoon, Hinckley waited outside the Washington Hilton and, when the President emerged, Hinckley shot six times, seriously wounding the President and four others.

II.

Gaplan presents these facts in considerably more detail and with greater emphasis on Hinckley's familial and emotional history, but these basic facts underlay both the government and defense theories presented during Hinckley's trial. The government emphasized the premeditated nature of Hinckley's actions: Hinckley had bought a gun; followed President Carter; traveled to Washington; left a note stating his intentions; selected Devastator bullets from among the ammunition he had on hand; waited for President Reagan to leave the hotel; and fired six shots at the President.

To the defense, these same actions were indications of Hinckley's mental illness. Hinckley was obsessed with the story of Taxi Driver and with attracting Foster's attention. He hoped to win the affection of Jodie Foster by killing the President. Hinckley may have intended to assassinate the President, but he ultimately did so only because he was suffering delu-

8. P. 11. 
sions that rendered him incapable of behaving in a sane, responsible fashion.

Because of this difference between the government and defense theories of Hinckley's behavior, his trial came to focus on opposing teams of psychiatric experts-Park Dietz and Sally Johnson for the government, and William Carpenter and David Bear for the defense. Dr. Bear was particularly visible during the trial because of his challenges to the manner in which the law deals with psychiatric diagnoses. At the time of Dr. Bear's testimony, Judge Barrington Parker had ruled that the defense could not introduce into evidence a GAT-scan of Hinckley's brain. Dr. Bear lectured the court on the role of the CAT-scan in his diagnosis and announced that "I would like the right to state to the jury that an important test which I use in reaching my conclusions has been barred by the court and I was not able to present it to the jury, though I believe it would influence their decision as it has influenced mine."9

Dr. Bear's concern nicely touches upon two issues likely to catch the attention of any trial lawyer: the quality of evidence used to prove the state of mind of a defendant, and the proper role of a psychiatrist at a criminal trial. The mens rea element of a criminal offense is, almost by definition, more difficult to establish than the actus reus element. Videotape can capture a politician taking money and putting it into a briefcase, but no scientific instrument can directly monitor the interior workings of the politician's mind. A jury is necessarily left to sift through circumstantial evidence of a defendant's external actions and statements in order to discern the defendant's knowledge and intent. That task is difficult enough when $A$ strikes $B$, and $A$ says he acted out of fear of imminent attack. The jury's role is much more complex when $A$ strikes $B, A$ says he is insane and, as in the Hinckley case, competing experts offer the jury conflicting psychiatric diagnoses.

At the Hinckley trial, defense attorneys hoped to use tangible evidence-a CAT-scan of Hinckley's brain-to diminish the uncertainty surrounding Hinckley's mental state. Dr. Bear told the court that the CATscan showed widened folds and ridges (sulci) and that such widened sulci appear more frequently in schizophrenics (one of three) than in the normal population (one of fifty). ${ }^{10}$ Over the government's objections, the defense eventually convinced the court to rule that the CAT-scan was evidence relevant to their claim that Hinckley was a schizophrenic.

This episode reflects the skepticism with which the law treats scientific evidence: Only evidence that is demonstrably reliable is permitted to go to

9. P. 84. Judge Parker subsequently reversed his decision to forbid the defense to introduce the CAT-scan into evidence. See p. 85.

10. P. 80 . 
the jury. ${ }^{11}$ The admission of unreliable evidence-especially unreliable evidence cloaked in a patina of scientific authority-may result in unfair verdicts and, over time, in unequal application of the law to similarlysituated defendants. From Dr. Bear's point of view, the judicial reluctance to recognize as probative all of the data relied upon by a diagnostician seemed to thwart the psychiatrist's role as expert witness. From the law's viewpoint, that reluctance is necessary to protect the jury's independence and its ability to reach a just decision.

As Mr. Caplan explains in two chapters that lie at the heart of the book, psychiatric testimony has become essential to any trial involving the insanity defense. Indeed, such testimony has now assumed constitutional dimensions. In Ake v. Oklahoma ${ }^{12}$ the Supreme Court reversed the conviction and death-sentence of an indigent defendant. At trial, the defendant had requested, but had been denied, access to a psychiatrist. The Supreme Court held that "when a defendant has made a preliminary showing that his sanity at the time of the offense is likely to be a significant factor at trial, the Constitution requires that a State provide access to a psychiatrist's assistance on this issue, if the defendant cannot otherwise afford one."1s The Court's holding is grounded squarely on the requirements of due process. The Court concluded that the defendant's interest in presenting an insanity defense is great, the state's interest in refusing to provide psychiatric assistance is slight, and that, absent such assistance, "the risk of an inaccurate resolution of sanity issues is extremely high."14

The Court's analysis of the psychiatrist's role brings two contrasting views into sharp relief. To the majority in $A k e$, a psychiatrist is needed not just to provide expert testimony but also to assist counsel in their presentation and cross-examination of the experts for the other side. Thus, the Court explained that psychiatrists "know the probative questions to ask of the opposing party's psychiatrist"15 and that their assistance is needed "to conduct a professional examination on issues relevant to the defense, to help determine whether the insanity defense is viable, to pre-

11. See Frye v. United States, 293 F. 1013 (D.C. Cir. 1923) (holding systolic-blood-pressure deception test inadmissible); MCCoRmick's HaNdBOOK of THE LAW of Evidence 31 (E. Cleary 2d ed. 1972) ("IO]pinion evidence is not admissible if the court believes that the state of the pertinent art or scientific knowledge does not permit a reasonable opinion to be asserted even by an expert.").

12. 53 U.S.L.W. 4179 (U.S. Feb. 26, 1985).

13. Id. at 4181 .

14. Id. at 4183. Chief Justice Burger, concurring in the judgment only, contended that the majority opinion does not apply to non-capital cases. Id. at 4184 . Justice Rehnquist, in dissent, did not share that view of the Court's holding, id. at 4184-86 (Rehnquist, J., dissenting), nor does the majority's analysis support Chief Justice Burger's interpretation. My own view is that where a due process violation occurs at the guilt-determining phase of a trial, and where the Supreme Court reverses the underlying conviction instead of merely vacating a death sentence, there is no logical basis for distinguishing between capital and non-capital defendants.

15. Id. at 4182 . 
sent testimony, and to assist in preparing the cross-examination of a State's psychiatric witnesses ....."16

In dissent, Justice Rehnquist took aim at the majority's characterization of the psychiatric role. He concluded that "all the defendant should be entitled to is one competent opinion-whatever the witness' conclusion-from a psychiatrist who acts independently of the prosecutor's office."17 No more should be required because "[a] psychiatrist is not an attorney, whose job it is to advocate."18

Justice Rehnquist's view reflects the long-standing discomfort felt by laymen and lawyers alike when faced with contradictory expert testimony. Wigmore asserted that the partisanship of an expert witness clashes with "that ideal of impartiality and trustworthiness which is naturally associated with abstract scientific truth."19 But, as the Hinckley trial demonstrates, the majority view in Ake v. Oklahoma better captures the reality of the present-day courtroom.

Still, the question posed at the outset remains. On what basis does a juror confronted with irreconcilable expert opinions decide whether a defendant is insane? Caplan's treatment of the Rufus Adams trial may answer the question by analogy. Adams was charged with murder, rape, and sodomy. The expert for the defense described Adams as a paranoid schizophrenic; the expert for the prosecution conceded only that the defendant had "some difficulty with controlling his own feelings."

16. Id. at 4183 .

17. Id. at 4186 (Rehnquist, J., dissenting).

18. Id. This debate presages what will likely be the next constitutional issue adjudicated. The Court emphasized that the obligation of a state "is limited to provision of one competent psychiatrist ...."Id. at 4182. The first post-Ake question is sure to arise when the "one competent psychiatrist" finds that the defendant is sane and, therefore, refuses to provide the form of assistance contemplated by the majority opinion. The question for the Supreme Court will be whether the Constitution requires one psychiatrist or rather one defense-oriented psychiatrist, that is, whether the Constitution requires that an indigent defendant be permitted to interview psychiatrists until he finds one who believes that the defendant is insane.

If the analogy between legal and psychiatric assistance is exact, then the answer will be easy: An indigent defendant has a right to an attorney who will assist him, not just to one who listens patiently and advises him to plead guilty. But the Supreme Court may not follow that route. First, the majority opinion notes that one task of a psychiatrist is to help the defense to "determine whether the insanity defense is viable," thus suggesting that the majority contemplates situations in which the psychiatrist will conclude that the defense should not be raised. Id. at 4183 . Second, the Supreme Court may conclude that the risk of an erroneous verdict is not unconstitutionally high where an independent psychiatrist concludes that there is no basis for an insanity defense. Such a decision would not, of course, limit the ability of wealthier defendants to search out sympathetic expertise. See Saltzburg, Privileges and Professionals: Lawyers and Psychiatrists, 66 VA. L. REv. 597, 635-42 (1980).

19. 2 J. Wigmore, Evidence in Trials at Common LAw § 563, at 760 (J. Chadbourn rev. ed. 1979). Wigmore's "solution" to the battle of experts-authorizing the court to select an expert who would testify in addition to the parties' experts-is incorporated into Rule 706 of the Federal Rules of Evidence. That provision has been seldom used, perhaps because judges as a group "remain committed to adversarial responsibility for presenting evidence." $3 \mathrm{~J}$. WeINSTEIN \& M. BERGER, WEINSTEIN's EvIDENCE I 70602, at 706-12 (1982).

20. P. 54. 
victed the defendant on five counts, but acquitted him by reason of insanity on the sixth count, which charged that he sodomized the victim after her death. The jury was willing to conclude that a sane person could murder and rape, but as one juror explained, "[it's] not a normal thing, for a man to sodomize a dead body." jury based its decision on its collective common sense.

III.

To many people, however, the Hinckley verdict of not guilty by reason of insanity defied common sense. Caplan, in his concluding chapters, analyzes the efforts to have Congress alter the insanity defense by: (i) either abolishing the defense (the plan initially favored by the Reagan Administration), or revising the defense in conformity with the A.P.A. standard; (ii) shifting the burden of proof to the defendant; or (iii) limiting the ability of psychiatrists to testify on the ultimate issue, that is, to offer an opinion on whether a defendant is, in fact, legally insane.

Caplan quite properly devotes most of his attention to the issue of abolishing the insanity defense. $\mathrm{He}$ argues that those who wish to change the insanity defense overlook a basic, widely-held belief that "a man's free will could be limited by mental illness." the question as one of "protecting the rights of criminals versus those of society, the forces of law against lawlessness." ${ }^{\text {"23 }}$ Caplan notes that the Reagan Administration had retreated from the abolitionist position by 1984 , but that the Senate in the same year passed the Insanity Defense Reform Act, ${ }^{24}$ which codifies the A.P.A. standard. He suggests that the Senate demonstrated "a willingness to give up a civilized standard for a harsh reminder of the balance of power between the individual and society. $\$ 25$

The general thrust of Caplan's analysis is sound, but his conclusion is overstated. He errs, I believe, by not distinguishing between the Reagan Administration's original position-favoring abolition of the insanity defense-and the more limited revisionist position ultimately embraced by the Senate and, after the book's publication, by the House. As demonstrated by the second hypothetical discussed above, the new congressional formulation does not abolish the insanity defense, although it does eliminate the "volitional" prong of the A.L.I. proposal.

Caplan is quite right to argue that the debate over the existence of the

21. P. 56.

22. P. 3.

23. P. 3.

24. See supra note 5 .

25. P. 127 . 
insanity defense represents a fundamental moral choice for our legal system. We affirm our belief in free will by recognizing that legal culpability cannot attach to a person who, by reason of mental defect or disease, cannot choose freely. It is not clear, however, that Congress' revision of the insanity defense demonstrates "a willingness to give up a civilized standard," especially since the new law reaffirms the right of a defendant to be acquitted if he "was unable to appreciate the nature and quality or the wrongfulness of his acts." 26

The failure to distinguish between the abolitionist and revisionist views may obscure a second ground for opposition to the insanity defense. It is possible that opposition to verdicts such as that in the Hinckley trial springs, at least in part, from widespread societal distrust of psychiatry and the reliability of its diagnoses. One expression of that distrust in everyday life is the stigma that attaches in some social groups to a person who seeks psychiatric help. ${ }^{27}$ Of course, no similar social opprobrium attaches to one who consults an orthopedic surgeon for treatment of a knee injury or an opthalmologist for a prescription for new glasses.

I do not mean to suggest that Americans do not believe that mental illness exists in its most extreme forms. But, as the government repeatedly emphasized during the trial, John Hinckley did not display a complete or extreme inability to function in society. He traveled on his own, followed President Carter to two campaign stops, formed a plan to assassinate President Reagan, and, when he loaded his gun, carefully selected Devastator bullets. To the many Americans who doubt the validity of the Hinckley verdict, ${ }^{28}$ these facts may suggest that a sane man was kept from jail with the assistance of doctors skilled in an inexact discipline.

Public statements during the congressional debate over the 1984 Act support the view that wariness of psychiatric diagnoses fueled the abolitionist and revisionist efforts. Former Attorney General Smith, for example, criticized the insanity defense because "the disagreement of supposed experts is perhaps so basic that it makes the jury's decision rationally impossible."29 In more measured tones, the American Bar Association supported elimination of the "volitional" element of the defense by arguing that:

26. Pub. L. No. 98-473, $\S 402,1984$ U.S. CODE CoNG. \& AD. NEwS (98 Stat.) 2057 (to be codified at 18 U.S.C. $\$ 20$ ).

27. Popular entertainment presentations, for example, assume such attitudes exist. In the Hill Street Blues television episode of January 17, 1985, for example, a character decried the fact that police officers send silent and subtle signals to troubled members of the force that they will not be trusted if they seek psychiatric assistance.

28. Caplan reports that an ABC News poll taken the day after the verdict showed that $83 \%$ of the nation "thought justice was not done in the Hinckley trial." P. 116.

29. P. 115 (emphasis added). 
During the 1950s a wave of clinical optimism suggested that scientific knowledge concerning psychopathology had expanded to the extent that informed judgments could be made regarding impairment of behavioral control. That optimism was reflected in the volitional portion of the ALI test. Yet, experience confirms that there is still no accurate scientific basis for measuring one's capacity for self-control or for calibrating the impairment of such capacity. There is, in short, no objective basis for distinguishing between offenders who were undeterrable and those who were merely undeterred, between the impulse that was irresistible and the impulse not resisted, or between substantial impairment of capacity and some lesser impairment. ${ }^{30}$

Even the American Psychiatric Association has recognized the limits on the reliable use of psychiatric testimony. It has championed the exclusion of psychiatric testimony in death-sentence proceedings in which psychiatrists may be called upon to make long-term assessments of the future dangerousness of a defendant. ${ }^{31}$ The A.P.A. also urged Congress to eliminate the volitional element of the insanity defense because "[t]he line between an irresistible impulse and an impulse not resisted is probably no sharper than that between twilight and dusk."32

Of course, doubts about the reliability of psychiatric testimony raise the same issue involved in the dispute over the admissibility of the CAT-scan of Mr. Hinckley's brain. If psychiatry were determined to be a discipline without support in scientific fact, then why shouldn't psychiatric testimony, like the results of polygraph tests, be excluded from criminal trials? From this vantage point, suspicion of the insanity defense need not be excoriated simply as a "step toward tyranny." as an understandable concern over the manner in which psychiatric analysis has been employed in support of the insanity defense.

Congress' passage of the Insanity Defense Reform Act of 1984 did not,

30. Pp. 119-20.

31. See Barefoot v. Estelle, 103 S. Ct. 3383, $3397-99$ (1983) (discussing views of A.P.A.); id. at 3408-09 (Blackmun, J., dissenting) (same).

32. American Psychiatric Association, supra note 6, at 11 . In addition, the A.P.A., while recognizing the ability of psychiatrists reliably to diagnose a person's present or past mental condition, cautioned against expert testimony that attempts to fit psychiatric analysis into legal terminology. Congress responded to this critique by enacting an evidentiary provision in $\S 406$ of the Insanity Defense Reform Act of 1984:

No expert witness testifying with respect to the mental state or condition of a defendant in a criminal case may state an opinion or inference as to whether the defendant did or did not have the mental state or condition constituting an element of the crime charged or of a defense thereto. Such ultimate issues are matters for the trier of fact alone.

Pub. L. No. 98-473, $\S 406,1984$ U.S. Code Cong. \& Ad. News (98 Stat.) 2067-68 (to be codified as Rule 704(b) of the Federal Rules of Evidence). Caplan suggests that this change alone will have little effect on the jury's ability to sift through expert testimony: By his calculation, only 26 of 7,342 transcript pages from the Hinckley trial contained medical testimony on the ultimate issue of the defendant's sanity. P. 122.

33. P. 5. 
by any means, constitute a wholesale rejection of psychiatric diagnosis or psychiatric testimony in criminal proceedings. By eliminating the "volitional" element of the defense and placing new evidentiary restrictions on psychiatric testimony, Congress indicated a desire to recognize the limits of psychiatric expertise. Neither these changes, nor the separate decision to shift the burden of proof to the defendant, appears to justify Caplan's conclusion that these legislators were simply accepting the Reagan Administration's injunction that "their choice was between the forces of law and the forces of lawlessness."

Gaplan directs only one specific criticism at the choice by Congress to eliminate the volitional element of the insanity defense. He states that "[t]he logic of the sponsors [of this change] was strong enough to overwhelm their sense of reality." insufficient: "Riveted on the fine points of language, [the sponsors] seemed to think juries using their new wording would be made up of philologists, or even lawyers and psychiatrists, who were trained to pick up all shades of language." ${ }^{\text {se }}$

Two difficulties arise from Caplan's analysis. First, the language at issue does not appear to be unusually abstruse. The A.L.I. standard states that "A person is not responsible for criminal conduct if at the time of such conduct as a result of mental disease or defect he lacks substantial capacity either to appreciate the criminality (wrongfulness) of his conduct or to conform his conduct to the requirements of law."s7 The new statute basically tracks the first half of that language and omits the phrase "or to conform his conduct to the requirements of the law." that language should not require advanced academic training. ${ }^{39}$

Second, Caplan's criticism is essentially nihilist: The language of the jury instruction makes little if any difference. The nihilist view, however,

\footnotetext{
34. P. 127.

35. P. 120.

36. Pp. 120-21.

37. Model Penal Code $\S 4.01$, at 66 (Proposed Official Draft 1962).

38. The Insanity Defense Reform Act of 1984 provides that:

It is an affirmative defense to a prosecution under any Federal statute that, at the time of the commission of the acts constituting the offense, the defendant, as a result of a severe mental disease or defect, was unable to appreciate the nature and quality or the wrongfulness of his
} acts.

Pub. L. No. 98-473, § 402(a), 1984 U.S. Code Cong. \& AD. News (98 Stat.) 2057 (to be codified at 18 U.S.C. $\S 20(a))$.

39. It does not seem any more complex, for example, than a standard jury instruction defining "malice aforethought":

"Malice aforethought" means an intent, at the time of a killing, willfully to take the life of a human being, or an intent willfully to act in callous and wanton disregard of the consequences to human life; but "malice aforethought" does not necessarily imply any ill will, spite or hatred towards the individual killed.

2 E. DevitT \& C. Blackmar, Federal Jury Practice and Instructions $\$ 41.05$ (3d ed. 1977). 
merely doubts the utility of any change in the wording of the insanity defense; it does not force one to conclude that revision will worsen the state of affairs. If the change instituted by the new statute is theoretically sound-and Caplan does not challenge Congress' view that it is-then Caplan's analysis fails to explain why Congress should not have acted.

In sum, concern about and opposition to the insanity defense as defined by the jury charge in the Hinckley case and the A.L.I. standard need not result merely from a heartless attempt to sacrifice individual liberty. The reliability of jury verdicts, and therefore the guarantee that the law will be applied equitably, necessarily depends on the probative value of evidence and expert opinion presented to the jury. When significant data suggest that the insanity defense may be encouraging the use of psychiatric testimony in a manner that is neither exact nor verifiable, revision of the insanity defense to reflect that concern is wholly justifiable. To this observer at least, Congress' decision to reject the abolitionist view in favor of revising the defense seems eminently sound.

\section{IV.}

This criticism of one of Caplan's conclusions should not, however, obscure the strengths of his book. Caplan's reporting of the Hinckley trial is excellent. As an observer of some small portions of that litigation, I was able to watch the lawyers for the government and for Hinckley at work. Gaplan has nicely captured the lawyers' individual personalities and, I think, the manner in which their considerable talents presented the jury with two compelling, if inconsistent, views.

More important, Caplan, through descriptions of John Hinckley and quotations from his writings, has made Hinckley's personality come alive. Without some understanding of Hinckley, it is not possible to comprehend the jury's verdict. Indeed, I think that the popular disapproval of the jury's decision resulted largely from a failure to realize the degree to which John Hinckley was genuinely affected by his obsessions. When I listened to the tape recording of the New Year's musings that Hinckley made at the end of 1980, I was reminded of the Edvard Munch painting, "The Cry," which depicts an unheard shout echoing through a bleak landscape. Gaplan similarly paints the picture of a man who inhabits a world by himself.

Caplan also adroitly mixes factual description with the identification of important social issues. The law, even criminal law, can be a dry subject. But Caplan uses the now-famous facts of the Hinckley trial to identify and discuss the fundamental social and legal questions surrounding the use of the insanity defense. He recognizes, I think, that the criminal law is too important to be left to lawyers, and that the definition of insanity is 


\section{Insanity Defense}

too basic to our views of social justice to be abandoned to the diagnoses of psychiatrists. He requires us to confront the rationale for the insanity defense, the reasons why it has fallen upon disfavor, and the varying factors-like the amount of money that a defendant has to mount a defense-that affect the use of the defense in the real world.

In the end, Caplan presents a pessimistic view of the willingness of citizens and legislators to stand up for civil rights. As noted above, Caplan's specific criticisms may be overstated, but his basic conclusion surely is not. In an era in which the pendulum of public opinion seems to be swinging towards social conformity, the rights of the different-of religious minorities, of criminal defendants, of the mentally ill--may seem of little importance. Those who read Caplan's book will be reminded, however, that unpopular results are not synonymous with jurisprudential error. 
